\title{
Supply chain integration: direction, extent and ballance
}

\author{
Erik Selldin and Jan Olhager \\ Linköping Institute of Technology, Department of Production Economics, SE - 58183 \\ Linköping, Sweden
}

\begin{abstract}
Supply chain management practices and principles are evolving and changing rapidly, for example through modern information and communication technologies. These changes affect the ways supply chains are designed, the way they are managed, and how planning and control activities take place within these chains. This paper empirically analyses supply chain integration strategies in a survey sample of 128 Swedish manufacturing firms. We specifically study issues related to the relationships with supply chain partners: the direction and extent of integration, and the types of collaboration. The impact of supply chain collaboration and coordination ability on firm performance and profitability is analysed. Further, the implications of our findings for future supply chain strategies and practices are discussed.
\end{abstract}

\section{Keywords}

Supply chain management, Integration, Collaboration, Coordination.

\section{INTRODUCTION}

Over the past decade there has been a growing consensus concerning the strategic importance of integrating suppliers, manufacturers, and customers (Frohlich \& Westbrook, 2001). Typically, the goal is to create and coordinate manufacturing processes seamlessly across the supply chain in a manner that most competitors cannot very easily match (Lummus et al., 1998). Growing evidence suggests that the higher the level of integration with suppliers and customers in the supply chain, the greater the potential benefits (Narasimhan \& Jayaram, 1998; Lummus et al., 1998; Frohlich and Westbrook, 2001; Lowe and Markham, 2001). However, these studies do not control for type of product or type of supply chain, thus ignoring that there may be situational dependencies that lead to different types of integration initiatives or activities. Fisher (1997) presents a typology for distinguishing between products and supply chains for choosing the right supply chain for a product. The foundation is that products can be either functional or innovative depending on their demand pattern and market expectations. A supply chain on the other hand can either have a strong physical function in delivering the goods or a market mediating function for conveying information. Fisher (1997) presumes that a functional product requires a physical efficient supply chain whereas 
an innovative product requires a market responsive supply chain. There are still a number of questions concerning how firms should act to integrate supply chain operations efficiently. Therefore, it is vital to be able to check for the impact on performance.

In this paper we present a survey of supply chain practices in Swedish manufacturing firms, concerned with supply chain integration strategies from the perspective of the individual manufacturing firm. We capture the strategic intent, principles and practices of supply chain integration and its effect on performance. The paper is organised as follows. First, we discuss the research methodology and the characteristics of the responding enterprises. Then we present and analyse the survey results, divided into sections on supply chain strategy and performance, direction, extent, and balance. The concluding remarks include managerial implications.

\section{RESEARCH METHODOLOGY}

The survey reported here was mailed to 511 manufacturing firms in May 2001. The Swedish Production and Inventory Management Society, PLAN, provided the mailing lists. The authors mailed the questionnaire to the entire body of PLAN members in Swedish manufacturing firms. By October 2001, 128 usable responses were received for a response rate of 25.0 percent, which must be considered to be satisfactory for this type of survey. The survey employs three question formats: Likert scales, multiple response, and metric measurement scales. The basic results, indicating the status of supply chain strategy issues, are presented in Olhager and Selldin (2002), and a focussed study on the linkage between product characteristics and supply chain design is presented in Selldin and Olhager (2002).

The majority of the responding firms have annual revenue of $\$ 50$ million or less, and fewer than 500 employees. However, the sample also includes large corporations and large divisions within corporations. The sample includes a variety of order penetration points: make-to-order dominate in approximately 60 percent of the firms and 30 percent of the firms are dominated by MTS. All five fundamental process choices are represented: project, job shop, flow shop, line, and continuous process. Since all respondents belong to the Swedish production and inventory management society, they are professionally involved in questions and problems related to supply chain operations.

\section{SUPPLY CHAIN INTEGRATION}

Integration along a supply chain can be treated as vertical integration. However, vertical integration is traditionally considered as the degree to which an organization owns the network of processes which together give goods their value (Slack, 1997), and is normally discussed in terms of direction, extent and balance, as suggested by Hayes and Wheelwright (1984). The fundamental concerns of direction and extent treat the boundaries of the firm and whether the organization should broaden or narrow the span of its operations, whereas balance deals with the resulting vertically 
linked activities, in terms of how dependent the suppliers and customers are on the firm, relative how dependent the firm is on its suppliers and customers.

In this paper, we take a slightly different view on integration. By supply chain integration we mean collaboration and coordination issues between firms in successive positions along a supply chain. We adopt the three policy areas of vertical integration, i.e. direction, extent and balance, but we interpret them differently since we deal with supply chain integration rather than vertical integration. Direction is related to the dominance and criticality of the linkages upstream and downstream the supply chain: i.e. which direction is more important or critical? Extent is concerned with the use of supply chain planning systems and collaborative efforts: i.e. to what extent do companies collaborate in planning activities? Balance, finally, deals with the overall perception of what is important along the supply chain: i.e. how do companies choose partners, relative the primary purpose of the supply chain design?

Before presenting and analysing the results concerning direction, extent and balance, we present the results reflecting the strategic intent and performance of the manufacturing firms with respect to the supply chain operations.

\section{SUPPLY CHAIN STRATEGY}

In this section we report on the overall objectives and practices of the firm and its effect on performance. The overall objective refers to the primary purpose of the supply chain design according to Fisher (1997), which can be either (i) supply predictable demand efficiently at the lowest possible cost ("minimise cost") or (ii) respond quickly to unpredictable demand in order to minimize stock-outs, forced markdowns, and obsolete inventory ("quick response"). The scale used was a Likert scale from 1 to 5 representing "not important" to "very important". The ability of the companies to coordinate the supply chain was used as an overall perception of supply chain integration, ranging from "very poor" to "very good" on a 5-point Likert scale. Finally, performance was measured in terms of profitability and manufacturing-related competitive priorities such as quality, delivery speed and dependability, productivity (for price competition), and flexibility (volume and product mix) on a 5-point Likert scale ranging from "much worse than competitors" to "much better than competitors". The correlations among these variables are shown in Table 1.

Table 1 shows that there is a significant positive correlation between the two strategies in terms of the primary purpose of the supply chain. Thus, these are not mutually exclusive; rather it seems that companies may try to pursue both objectives. There are some positive correlations between performance variables, indicating that companies pursue more than a single performance measure, and that they also perform well - or poor - in a variety of areas simultaneously. This can also be interpreted such that some performance measure variables are mutually supportive. For example, there is strong internal correlation between the two delivery measures, i.e. speed and dependability, as well as between the two flexibility measures, i.e. volume and product mix. Furthermore, there is strong positive correlation between the two flexibility measures and the two delivery 
measures, which can be interpreted such that volume and product mix flexibility is useful for achieving delivery speed and dependability.

Table 1 - Pearson correlations for supply chain strategy (variable 1 - 2), ability to coordinate (3), and performance measures (4 - 10).

\begin{tabular}{|c|c|c|c|c|c|c|c|c|c|}
\hline Variable & 1 & 2 & 3 & 4 & 5 & 6 & 7 & 8 & 9 \\
\hline 1. Minimise cost & 1 & & & & & & & & \\
\hline 2. Quick response & $.288 * *$ & 1 & & & & & & & \\
\hline $\begin{array}{l}\text { 3. Supply chain } \\
\text { coordination ability }\end{array}$ & -.014 & $.273^{* * *}$ & 1 & & & & & & \\
\hline 4. Product quality & .006 & .165 & .088 & 1 & & & & & \\
\hline 5. Delivery speed & .038 & .159 & $.221 *$ & .104 & 1 & & & & \\
\hline 6. Delivery dependability & -.021 & $.226^{*}$ & $.245^{*}$ & .020 & $.721 * *$ & 1 & & & \\
\hline 7. Productivity & .111 & .126 & .148 & $.189 *$ & $.189^{*}$ & .135 & 1 & & \\
\hline 8. Volume flexibility & .126 & .142 & .168 & -.053 & $.300 * *$ & $.255^{* * *}$ & $.195^{*}$ & 1 & \\
\hline 9. Product mix flexibility & .098 & .096 & .065 & .138 & $.250 * *$ & $.208^{*}$ & $.224 * *$ & $.503^{* * * *}$ & 1 \\
\hline 10. Profitability & $-.216^{*}$ & .051 & $.291 * *$ & .143 & .033 & .085 & $.351 * *$ & .013 & -.012 \\
\hline
\end{tabular}

Supply chain coordination ability is positively correlated to the quick response strategy. It is reasonable that it is important to be able to coordinate the supply chain in order to respond quickly to changing demands. The coordination ability is also positively correlated to delivery speed and dependability, at the same time as quick response strategy is positively correlated to delivery dependability. It is clear that there is a connection between the quick response, coordination ability and delivery measures.

Profitability, the bottom line of company performance, is positively correlated with supply chain coordination ability and productivity. The ability to coordinate may provide the company with quick, on-time deliveries whereas productivity is useful for cost efficiency. However, profitability is not significantly correlated with any of the other performance measures, and is negatively correlated to the cost minimisation strategy. The latter result can be interpreted such that companies having high profits do not need to chase costs, and that companies with low profits may be more eager to cut costs.

\section{DIRECTION}

Direction is related to two issues, i.e. dominance and criticality along the supply chain. The first aspect is related to the position of the dominating actor, whether it is the company itself or the first or second tier upstream or downstream partner. The position of the dominating actor was combined with the ability of coordinating the supply chain and analysed with respect to profitability, and the result is shown in Table 2. We have reduced the number of dominance position to three, by combining first and second tier suppliers into one group, and first and second tier customers into one group. We have also combined "very poor" and "poor" ability to coordinate as well as "good" and "very good". Thereby we have a minimum of 4 companies in each combined cluster and a maximum of 22 . 
The results show that the correlation between the position of the dominating actor in the supply chain and profitability is not statistically significant. There is however a tendency that companies, with average or good ability to coordinate and that dominate in their respective supply chains, are more profitable than those where the dominating actor is upstream or downstream. Also, the companies with poor ability to coordinate seem to be more profitable if the dominating actor is upstream; thus benefiting from being on the customer side of the dominating actor. Companies upstream the dominating actor show very poor performance, which may be interpreted such that these companies are under pressure from their dominating customers restricting their profit opportunities.

Table 2 - Profitability levels relative the supply chain position of the dominating actor.

\begin{tabular}{|c|c|c|c|c|}
\hline & \multicolumn{4}{|c|}{ Dominating actor } \\
\hline $\begin{array}{l}\text { Ability to } \\
\text { coordinate }\end{array}$ & $\begin{array}{c}\text { Supplier } \\
\text { (Iilist or second } \\
\text { tier) }\end{array}$ & Company & $\begin{array}{c}\text { Customer } \\
\text { (fin'st or second } \\
\text { tier) }\end{array}$ & Average \\
\hline Very poor - poor & $4.00(4)$ & $3.17(6)$ & $2.29(7)$ & $3.00(17)$ \\
\hline Average & $3.40(5)$ & $3.82(22)$ & $3.53(17)$ & $3.66(44)$ \\
\hline Good - very good & $3.78(9)$ & $4.17(12)$ & $3.89(19)$ & $3.95(40)$ \\
\hline Average & $3.72(18)$ & $3.83(40)$ & $3.49(43)$ & $3.66(101)$ \\
\hline
\end{tabular}

The criticality of upstream vs. downstream operations is negatively correlated; see Table 3. This was expected, since if upstream operations are critical, then downstream operations are less critical. The ability to coordinate is significantly and positively correlated with downstream operations being critical to plan. Thus, if the planning of downstream operations is critical it is important to possess the ability to coordinate the supply chain. On the other hand, if upstream operations are more critical to plan, coordination seems to be left to the dominating actor, which is positioned upstream. This result is coherent with the previous observation that companies can be more profitable when the ability to coordinate is poor if the dominating actor lies upstream. As shown in Table 3, the impact on profitability is insignificant with respect to whether upstream or downstream operations are more critical to plan.

Table 3 - Pearson correlations related to whether upstream or downstream operations are more critical.

\begin{tabular}{lcccc}
\hline \multicolumn{1}{c}{ Variable } & 1 & 2 & 3 \\
\hline 1. Critical to plan upstream operations & 1 & & \\
2. Critical to plan downstream operations & $-.237 * *$ & 1 & 1 \\
3. Ability to coordinate & .061 & $.207 *$ & .076 & $.291 * *$ \\
4. Profitability & -.112 & -.076 \\
\hline
\end{tabular}

* correlation is significant at the 0.05 level

$* *$ correlation is significant at the 0.01 level 


\section{EXTENT}

Extent is related to the use of supply chain planning and control systems and collaborative efforts in the supply chain, i.e. to what extent do companies collaborate in supply chain activities. We examine the degree to which the partners in the supply chain are incorporated in the supply chain planning (SCP) system, including the focal company, its first tier partners, and second tier partners. The extent of the planning system is compared to the different domains of collaboration, i.e. collaborative forecasting, collaborative inventory planning, collaborative production planning, and collaborative capacity planning. Further, the effect on the ability to coordinate their supply chains is examined, and finally, the impact on profitability.

Table 4 - Pearson correlations for the utilization of supply chain planning and control systems (variable 1 - 5), ability to coordinate (6), collaborative initiatives (7-10), and profitability (11).

\begin{tabular}{|c|c|c|c|c|c|c|c|c|c|c|}
\hline Variable & 1 & 2 & 3 & 4 & 5 & 6 & 7 & 8 & 9 & 10 \\
\hline $\begin{array}{l}\text { 1. SCP incl. } 2^{\text {nd }} \text { tier } \\
\text { suppliers }\end{array}$ & 1 & & & & & & & & & \\
\hline $\begin{array}{l}\text { 2. SCP incl. } 1^{\text {st }} \text { tier } \\
\text { suppliers }\end{array}$ & $.386^{* * * *}$ & 1 & & & & & & & & \\
\hline $\begin{array}{l}\text { 3. SCP incl. internal } \\
\text { op's }\end{array}$ & $.289 * *$ & $.653^{* * *}$ & 1 & & & & & & & \\
\hline $\begin{array}{l}\text { 4. SCP incl. } 1^{\text {st }} \text { tier } \\
\text { customers }\end{array}$ & $.227^{*}$ & $.488 * *$ & $.608^{* * *}$ & 1 & & & & & & \\
\hline $\begin{array}{l}\text { 5. SCP incl. } 2^{\text {nd }} \text { tier } \\
\text { customers }\end{array}$ & $.204^{*}$ & $.246^{*}$ & $.327 * *$ & $.514^{* * *}$ & 1 & & & & & \\
\hline $\begin{array}{l}\text { 6. Ability to } \\
\text { coordinate }\end{array}$ & .193 & $.373 * *$ & .147 & .151 & .070 & 1 & & & & \\
\hline $\begin{array}{l}\text { 7. Collaborative } \\
\text { forecasting }\end{array}$ & .151 & $.264^{* * *}$ & $.213^{*}$ & $.284 * * *$ & $.217^{*}$ & $.193^{*}$ & 1 & & & \\
\hline $\begin{array}{l}\text { 8. Coll. inventory } \\
\text { planning }\end{array}$ & .191 & $.318^{* * *}$ & $.198 *$ & .078 & .042 & .125 & $.408 * *$ & 1 & & \\
\hline $\begin{array}{l}\text { 9. Coll. production } \\
\text { planning }\end{array}$ & .148 & .170 & .112 & .038 & .085 & $.232^{*}$ & $.348 * *$ & $.449 * *$ & 1 & \\
\hline $\begin{array}{l}\text { 10. Coll. capacity } \\
\text { planning }\end{array}$ & .193 & $.291 * *$ & .147 & $.204 *$ & .127 & $.233 *$ & $.371 * *$ & $.389 * *$ & $.672 * *$ & 1 \\
\hline 11. Profitability & -.012 & .050 & .130 & -.004 & .117 & $.291 * *$ & -.075 & .013 & .149 & .067 \\
\hline
\end{tabular}

From Table 4 it can be concluded that the extent to which companies are including different partners in the supply chain planning systems are clearly correlated with each other. If a company has integrated one partner, it is likely to involve other partners as well. The different domains of collaboration are as well correlated with each other. If collaboration takes place in one domain it may very well take place in other domains as well. Companies having a high degree of integration with their first tier suppliers are also likely to have collaboration in several domains. Among the different forms of collaboration, collaborative forecasting is the one correlating with most of the planning system utilisation variables. This indicates that companies involving their partners in the supply chain planning may find collaborative forecasting the most attractive initiative. Collaborative production planning, on the other hand, does not correlate significantly with the use of supply chain planning systems. The ability to 
coordinate is positively correlated with the other three forms of collaborative initiatives, but only with first tier suppliers for SCP systems, indicating a priority for the supply side of the demand and supply chain. Finally, it can be noted that profitability is not significantly correlated with the utilization of a SCP system or with collaborative initiatives.

\section{BALANCE}

The issue of supply chain balance deals with the overall perception of what is important along the supply chain: i.e. how do companies choose partners relative the primary purpose of the supply chain design. We check for these issues relative (i) the primary purpose of the supply chain design; see Table 5, (ii) supply chain planning and control systems applications; see Table 6, and (iii) its impact on performance, including profitability; see Table 7.

Table 5 - Pearson correlations for supply chain strategy (variable 1 - 2) and criteria for strategic supply chain partner selection $(3-8)$.

\begin{tabular}{|c|c|c|c|c|c|c|c|}
\hline Variable & 1 & 2 & 3 & 4 & 5 & 6 & 7 \\
\hline 1. Minimise cost & 1 & & & & & & \\
\hline 2. Quick response & $.288 * *$ & 1 & & & & & \\
\hline 3. Product quality & .023 & $.298 * *$ & 1 & & & & \\
\hline 4. Delivery speed & $.286^{* *}$ & $.251 * *$ & $.298 * *$ & 1 & & & \\
\hline $\begin{array}{l}\text { 5. Delivery } \\
\text { dependability }\end{array}$ & .158 & $.364 * *$ & $.429 * *$ & $.411 * *$ & 1 & & \\
\hline 6. Cost efficiency & $.354 * *$ & .018 & -.141 & .033 & .022 & 1 & \\
\hline 7. Volume flexibility & $.255^{* * *}$ & $.331 * *$ & $.181 *$ & $.421 * *$ & $.361 * *$ & $.218 *$ & 1 \\
\hline $\begin{array}{l}\text { 8. Product mix } \\
\text { flexibility }\end{array}$ & .166 & $.202^{*}$ & .129 & $.210^{*}$ & $.293 * *$ & $.242^{* * *}$ & $.386^{* * *}$ \\
\hline
\end{tabular}

From Table 5 it is clear that companies emphasising one aspect in their partner selection also tend to see the other aspects as important. Studying the two supply chain strategies reveals that companies striving for cost minimisation choose partners that have high delivery speed, are cost efficient and have high volume flexibility. Companies that need quick response wants their partners to have high product quality, have high delivery speed and dependability, and have high flexibility both concerning volume and product mix. Again, as with performance measures, there are internal correlations between the delivery and flexibility issues. Also, it is notable that the cost minimisation strategy downplays the role of product quality, indicating the presence of a trade-off between cost and quality (which is supported by the fact that there is negative correlation between product quality and cost efficiency when choosing strategic partners), and that the quick response strategy downplays the role of cost efficiency, indicating that price is not an order winning criterion for quick response businesses.

When studying Table 6 it is revealed that companies having integrated their suppliers in the supply chain planning systems are interested in having partners that have high delivery speed, high delivery dependability, high volume flexibility, and to some extent high product mix flexibility. This is coherent with the previous result 
showing that the ability to coordinate was positively correlated with delivery speed and dependability in terms of performance measures. It is notable that companies with a quality or cost focus for partner selection are not likely to use supply chain planning systems.

Table 6 - Pearson correlations for the utilization of supply chain planning and control systems and criteria for strategic supply chain partner selection.

\begin{tabular}{|c|c|c|c|c|c|c|}
\hline & \multicolumn{6}{|c|}{ Partner selection croîteria } \\
\hline $\begin{array}{l}\text { Utilization of } \\
\text { Supply chain } \\
\text { planning and } \\
\text { control systems }\end{array}$ & Quality & $\begin{array}{l}\text { Delivery } \\
\text { speed }\end{array}$ & $\begin{array}{l}\text { Delivery } \\
\text { depend- } \\
\text { ability }\end{array}$ & $\begin{array}{c}\text { Cost } \\
\text { efficiency }\end{array}$ & $\begin{array}{l}\text { Volume } \\
\text { flexibility }\end{array}$ & $\begin{array}{l}\text { Product mix } \\
\text { flexibility }\end{array}$ \\
\hline $\begin{array}{l}\text { Incl. } 2^{\text {nd }} \text { tier } \\
\text { suppliers }\end{array}$ & .098 & $.321 * *$ & $.213^{*}$ & -.078 & $.246 *$ & $.249 *$ \\
\hline $\begin{array}{l}\text { Incl. } 1^{\text {st }} \text { tier } \\
\text { suppliers }\end{array}$ & .142 & $.257 * *$ & $.217 *$ & .105 & $.205^{*}$ & .133 \\
\hline $\begin{array}{l}\text { Incl. internal } \\
\text { operations }\end{array}$ & .136 & .102 & .127 & .096 & .180 & .137 \\
\hline $\begin{array}{l}\text { Incl. } 1^{\text {st }} \text { tier } \\
\text { customers }\end{array}$ & .013 & -.031 & .019 & -.016 & .045 & -.014 \\
\hline $\begin{array}{l}\text { Incl. } 2^{\text {nd }} \text { tier } \\
\text { customers }\end{array}$ & .169 & .030 & .025 & $-.212 *$ & .104 & .103 \\
\hline
\end{tabular}

In the cross checking between company performance and their selection criteria of supply chain partners (see Table 7), it would be expected to find a diagonal line of correlations. There is a match for quality, delivery dependability, volume flexibility, and product mix flexibility. For delivery speed there is no correlation for the performance or the selection criteria. It is interesting to see that there is no significant correlation between the company performance and any of the selection criteria. Therefore it is not possible to distinguish any partner selection criteria as being the best in a general case. Further analysis on combination of strategies must be carried out in order to see when the different criteria are most suitable.

Table 7 - Pearson correlations for criteria for strategic supply chain partner selection and its impact on performance.

\begin{tabular}{|c|c|c|c|c|c|c|}
\hline & \multicolumn{6}{|c|}{ Partner selection criteria } \\
\hline Performance & Quality & $\begin{array}{l}\text { Delivery } \\
\text { speed }\end{array}$ & $\begin{array}{l}\text { Delivery } \\
\text { depend- } \\
\text { ability }\end{array}$ & $\begin{array}{c}\text { Cost } \\
\text { efficiency }\end{array}$ & $\begin{array}{c}\text { Volume } \\
\text { flexibility }\end{array}$ & $\begin{array}{l}\text { Product mix } \\
\text { flexibility }\end{array}$ \\
\hline Product quality & $.183^{*}$ & .176 & .117 & -.069 & .000 & -.034 \\
\hline Delivery speed & .117 & .055 & .155 & .078 & .090 & .072 \\
\hline $\begin{array}{l}\text { Delivery } \\
\text { dependability }\end{array}$ & $.260 * *$ & .150 & $.251^{* *}$ & -.021 & .158 & $.188 *$ \\
\hline Productivity & $.210^{*}$ & .151 & $.297 * *$ & -.070 & .130 & .165 \\
\hline Volume flexibility & .112 & .088 & .172 & .019 & $.258 * *$ & $.246 *$ \\
\hline $\begin{array}{l}\text { Product mix } \\
\text { flexibility }\end{array}$ & -.014 & -.013 & .119 & .072 & .172 & $201 *$ \\
\hline Profitability & .127 & -.056 & .102 & -.150 & -.070 & -.018 \\
\hline
\end{tabular}




\section{CONCLUDING REMARKS}

In this paper we study the direction, extent and balance of supply chain integration in a survey of 128 Swedish manufacturing firms. We used a questionnaire survey to capture collaboration and coordination principles and practices. With a response rate of 25.0 percent of the contacted companies, this survey is able to provide a fairly accurate overview of the status of supply chain integration from a strategic perspective as well as from a tactical planning and control perspective.

The results indicate that the ability to coordinate the supply chain is a very important issue for profitability; especially when the company is the dominating actor in the supply chain. The study shows that delivery speed and dependability are strongly correlated, both as criteria for partner selection and as performance measures. The same is true for volume and product mix flexibility. Furthermore, these delivery and flexibility variables are strongly correlated; again, both as criteria for partner selection and as performance measures. If SCP systems are utilised it is used extensively involving more than one supply chain partner. The same is true for collaborative initiatives; if companies engage in one form of collaboration it is likely that they use all forms; i.e. forecasting, inventory planning, production planning, and capacity planning. Somewhat surprisingly, the use of SCP systems and collaborative initiatives, is not strongly correlated to the ability to coordinate the supply chain. Which factor that is the major constituent of the coordination ability remains to be identified; thus requiring further research.

\section{REFERENCES}

[1] Fisher, M. (1997): What is the right supply chain for your product?, Harvard Business Review 1997, Vol. 75, No. 2, pp.105-116.

[2] Frohlich, M.T. and Westbrook, R. (2001): Arcs of integration: an international study of supply chain strategies, Journal of Operations Management, Vol. 19, No. 2, pp. 185 200.

[3] Hayes, R.H. and Wheelwright, S.C. (1984): Restoring our Competitive Edge Competing Through Manufacturing, John Wiley \& Sons, New York, NY.

[4] Lowe, P.G. and Markham, W.J. (2001): Perspectives on operations excellence, Supply Chain Management Review, Vol. 5, No. 6, pp. 52 - 60.

[5] Lummus, R.R., Vokurka, R.J., and Alber, K.L. (1998): Strategic supply chain planning, Production and Inventory Management Journal, Vol. 39, No. 3, pp. 49 - 58.

[6] Narasimhan, R. and Jayaram, J. (1998): Causal linkages in supply chain management: an exploratory study of North American manufacturing firms, Decision Sciences, Vol. 29 , No. 3, pp. 579 - 605.

[7] Olhager, J. and Selldin, E. (2002): Supply chain strategies: a survey of Swedish manufacturing firms. Preprints, Twelfth International Working Seminar on Production Economics, Vol. 2, pp. 349 - 358.

[8] Selldin, E. and Olhager, J. (2002): Testing the fit between products and supply chains, in Christiansen JK and Boer $\mathrm{H}$ (Eds): Operations Management and the New Economy, Copenhagen Business School, 2002, pp. 1305 - 1314.

[9] Slack, N. (Ed.) (1997): The Blackwell Encyclopaedic Dictionary of Operations Management, Blackwell Publishers, Cambridge, MA. 